\title{
Fine-root mass, growth and nitrogen content for six tropical tree species
}

\author{
Oscar J. Valverde-Barrantes • James W. Raich • \\ Ann E. Russell
}

Published online: 20 May 2009

(C) Springer Science + Business Media B.V. 2009

\section{Erratum to: Plant Soil (2007) 290:357-370 DOI 10.1007/S11104-006-9168-2}

\begin{abstract}
Although fine roots might account for 50\% of the annual net primary productivity in moist tropical forests, there are relatively few studies of fine-root dynamics in this biome. We examined fine-root distributions, mass, growth and tissue $\mathrm{N}$ and $\mathrm{C}$ concentrations for six tree species established in 16year-old plantations in the Caribbean lowlands of Costa Rica in a randomized-block design $(\mathrm{n}=4)$. The study included five native species (Hyeronima alchorneoides, Pentaclethra macroloba, Virola koschnyi, Vochysia ferruginea and Vochysia guatemalensis) and
\end{abstract}

The online version of the original article can be found under doi:10.1007/s11104-006-9168-2.

O. J. Valverde-Barrantes $(\bowtie)$

Department of Biological Sciences, Kent State University, PO Box 5190, Kent, OH 44242-0001, USA

e-mail: ovalverd@kent.edu

J. W. Raich

Department of Ecology, Evolution and Organismal

Biology, Iowa State University, 253 Bessey Hall,

Ames, IA 50011, USA

e-mail: jraich@iastate.edu

\section{A. E. Russell}

Department of Natural Resource Ecology and

Management, Iowa State University, 339 Science II,

Ames, IA 50011, USA

e-mail: arussell@iastate.edu one exotic (Pinus patula). Under all species $>60 \%$ of the total fine-root mass to one meter deep was located in the uppermost $15 \mathrm{~cm}$ of the soil. Fine-root live biomass and necromass (i.e., the mass of dead fine roots) varied significantly among species but only within the uppermost $15 \mathrm{~cm}$, with biomass values ranging from $182 \mathrm{gm}^{-2}$ in Pinus to $433 \mathrm{gm}^{-2}$ in Hyeronima plots, and necromass ranging from $48 \mathrm{gm}^{-2}$ in Pinus to $183 \mathrm{gm}^{-2}$ in Virola plots. Root growth, measured using ingrowth cores, differed significantly among species, ranging from $261 \mathrm{gm}^{-2} \mathrm{yr}^{-1}$ in Pinus to $891 \mathrm{gm}^{-2} \mathrm{yr}^{-1}$ in Hyeronima. Turnover rates of fine root biomass ranged from 1.09 to $2.03 \mathrm{yr}^{-1}$ in Virola and Hyeronima plots respectively. Fine-root biomass was significantly and positively correlated with fine-root growth $(r=0.79, P<0.0001)$, but did not correlate with fine-root turnover $(r=0.10 ; P=0.20)$, suggesting that fine-root accumulation is a function of growth rate rather than mortality. Fine-root longevity was not correlated $(r=0.20, P=0.34)$ and growth was negatively correlated with root $\mathrm{N}$ concentration across species ( $r=-0.78, P<0.0001)$, contrary to reported trends for leaves, perhaps because $\mathrm{N}$ was relatively abundant at this site.

Keywords Fine-root biomass $\cdot$ Fine-root necromass Fine-root turnover $\cdot$ Root ingrowth $\cdot$ Tropical plantations 
Table 4 Annual fine-root ingrowth and turnover rates for six tropical species in 16-yr-old single-species plantations in lowland Costa Rica

Values are means (standard error, $n=4$ ) for the uppermost $15 \mathrm{~cm}$ of soil only. Different letters indicate significant differences among species (Tukey-Kramer HSD test; $\alpha=0.05$ )

\begin{tabular}{|c|c|c|c|}
\hline \multirow[t]{2}{*}{ Species } & \multirow{2}{*}{$\begin{array}{l}\text { Ingrowth rate } \\
\left(\mathrm{g} \mathrm{m}^{-2} \mathrm{yr}^{-1}\right)\end{array}$} & \multicolumn{2}{|c|}{ Turnover rate $\left(\mathrm{yr}^{-1}\right)$} \\
\hline & & Biomass & Carbon \\
\hline $\begin{array}{l}\text { Hyeronima } \\
\text { alchorneoides }\end{array}$ & $891(109)^{\mathrm{A}}$ & $2.03(0.10)^{\mathrm{A}}$ & $2.00(0.13)^{\mathrm{A}}$ \\
\hline $\begin{array}{l}\text { Pentaclethra } \\
\text { macroloba }\end{array}$ & $438(50)^{\mathrm{BC}}$ & $1.45(0.17){ }^{\mathrm{AB}}$ & $1.45(0.17) \mathrm{AB}$ \\
\hline Pinus patula & $261(30)^{\mathrm{C}}$ & $1.51(0.28)^{\mathrm{AB}}$ & $1.51(0.28){ }^{\mathrm{AB}}$ \\
\hline Virola koschnyi & $419(57)^{\mathrm{BC}}$ & $1.09(0.11)^{\mathrm{B}}$ & $1.06(0.10)^{\mathrm{B}}$ \\
\hline $\begin{array}{l}\text { Vochysia } \\
\text { ferruginea }\end{array}$ & $354(12)^{\mathrm{C}}$ & $1.46(0.12) \mathrm{AB}$ & $1.49(0.13) \mathrm{AB}$ \\
\hline $\begin{array}{l}\text { Vochysia } \\
\text { guatemalensis }\end{array}$ & $730(149)^{\mathrm{AB}}$ & $1.81(0.23)^{\mathrm{AB}}$ & $1.93(0.26)^{\mathrm{A}}$ \\
\hline
\end{tabular}

